\title{
APPLICATIONS OF INNOVATIVE COMPOSITE MATERIALS FOR SEISMIC STRENGTHENING OF MASONRY STRUCTURES
}

\author{
APLICACIONES DE MATERIALES COMPUESTOS INNOVADORES PARA \\ EL REFUERZO SÍSMICO DE ESTRUCTURAS DE MAMPOSTERÍA
}

\section{FRANCESCO MICELLI}

Los edificios de mampostería son propensos a colapsos frágiles bajo fuerzas sísmicas debido a su fragilidad y baja capacidad para resistir contra acciones cíclicas. En la mayoría de los casos las fallas se producen en forma de colapsos rígidos debido a la pérdida de equilibrio de partes estructurales enteras, y esto se debe a la baja calidad del detalle estructural 0 a fuerzas horizontales debido a bóvedas y arcos que aumentan su intensidad durante terremotos.

Todo el patrimonio arquitectónico está representado por la construcción de mampostería, también en las zonas sísmicas, por lo que una cuestión obligatoria consiste en preservar el valor histórico frente a acontecimientos naturales como terremotos. En los últimos años se emplearon nuevos materiales como sistemas de refuerzo para fines estructurales, y los materiales compuestos son los que han encontrado un amplio campo de aplicación en este contexto. En el trabajo se presentan nuevas soluciones estructurales para el reforzamiento sísmico y la adaptación, con referencia a aplicaciones reales en las que los materiales compuestos demostraron ser soluciones eficaces.

Las aplicaciones se presentarán con referencia a dos edificios históricos de mampostería, con diferentes esquemas de construcción; En el que pretensado PRF cables fueron diseñados y aplicados como estribos. Se estudió el uso de cables FRP para el primer edificio con referencia a los problemas de fisuras existentes, los cuales fueron investigados mediante técnicas no destructivas, inspecciones visuales y ensayos destructivos locales. El segundo caso reporta un estudio de vulnerabilidad sísmica para un gran edificio utilizado como teatro, en el que un análisis global fue acompañado de análisis cinemáticos que se realizaron bajo enfoques lineales y no lineales. Los resultados de los análisis permitieron comprender los posibles mecanismos de falla que debían ser inhibidos por un sistema de fortalecimiento estructural eficaz. También en este caso, el uso de cables PRP pretensados, de unos $40 \mathrm{~m}$ de longitud, demuestra ser el dispositivo estructural más eficaz en términos de costos y velocidad de aplicación. Los análisis sísmicos (globales y locales) serán ilustrados y discutidos en el trabajo, con referencia a las pruebas experimentales que fueron necesarias para la caracterización de las propiedades del material. Los resultados mostrarán cómo la presencia del sistema FRP es capaz de prevenir posibles colapsos de las paredes altas que están presentes en el edificio.

PALABRAS CLAVE: FRP, vulnerabilidad, mampostería, análisis cinemático, reforzamiento.
Masonry buildings are prone to brittle collapses under seismic forces due to their fragility and low capacity to resist against cyclic actions. In most cases failures occur in forms of rigid collapses due to loss of equilibrium of entire structural parts, and this is due to low quality of structural detailing or horizontal forces due to vaults and arches that increase their intensity during earthquakes.

The entire architectural heritage is represented by masonry construction, also in seismic areas, thus a mandatory issue consists of preserving the historical value against natural events such as earthquakes. In the last years new materials were employed as strengthening systems for structural purposes, and composite materials are those that have found a large field of application in this context. New structural solutions for seismic strengthening and retrofit are presented in the paper, with reference to real applications in which composite materials demonstrated to be effective solutions.

The applications will be presented with reference to two historical masonry buildings, having different construction schemes; in which pre tensioned FRP wires were designed and applied as ties. The use of FRP wires for the first building was studied with reference to the existing cracking problems, which were investigated by means of nondestructive techniques, visual inspections and local destructive tests. The second case reports a study of seismic vulnerability for a large building used as theatre, in which a global analysis was accompanied by kinematic analyses that were run under linear and non- linear approaches. The results of the analyses allowed understanding the possible failure mechanisms that needed to be inhibited by an effective structural strengthening system. Also in this case the use of FRP pre-tensioned wires, about $40 \mathrm{~m}$ long, demonstrate to be the most effective structural device in terms of costs and speed of application. The seismic analyses (global and local) will be illustrated and discussed in the paper, with reference to the experimental tests that were necessary for the characterization of the material properties. The results will show how the presence of the FRP system is able to prevent possible collapses of the high walls that are present in the building.

KEYWORDS: FRP, vulnerability, masonry, kinematic analysis, strengthening. 


\section{INTRODUCTION}

The heritage panorama in the southern Italy, Mediterranean countries and many other worldwide regions includes a large number of buildings made of unreinforced masonry (URM). Two main threats are usually considered in order to prevent possible limit states of historical masonry buildings: time and earthquakes. The first one is related to a slow and inexorable decay of the masonry due to settlements, structural modifications, materials degradation, vibrations, fatigue etc. All these elements are more quick in their action as higher the original engineering deficiencies are. The earthquakes are related to traumatic and quick events that may lead to sudden collapse or extensive damage when masonry is not well connected. Strengthening of the vertical elements in masonry construction subjected to dynamic actions (earthquake), in addition to its own weight, represents one of the most important measures for the achievement of an adequate level of structural safety. Another factor, which particularly affects the seismic behavior of a masonry structure, is the connection between vertical walls and between them and the horizontal structures. If present and effective, these connections can drive the building through a box-type behavior, assuring an adequate response against dynamic loads without loss of balance of individual portions. Without these connections, each individual element (a wall, a floor, a vault, etc.) is more vulnerable, being free to collapse independently from the rest of the construction. Different techniques are currently used for the strengthening of masonry buildings, such as traditional and innovative ones. Recent earthquakes have shown the vulnerability of such URM buildings. This study investigates about the seismic behavior of URM walls retrofitted by using pre-tensioned composites. The work includes an extensive linear and non-linear analysis. The main goal of the present paper is to present and demonstrate the validity of an innovative reinforcement technique which is able to significantly improve the global performance of a structure or a part of it by the application of FRP pre-stressed wires.

Two case studies will be presented herein, in which the first problem was related to the need of seismic upgrade of a public building due to the new seismic design code adopted in Italy; the second one was related to structural deficiencies due to construction defects, settlements and time-dependent properties of masonry.
CASE 1 - DESCRIPTION OF THE BUILDING

The building object of study is the cinema/theatre "The White Little Horse" in South of Italy, which was built after the II world war (starting of the theatre activities in 1949) and consists of three adjacent building systems with different roof levels (see figure 1):

1. The foyer

2. The auditorium.

3. The tower that houses the stage.
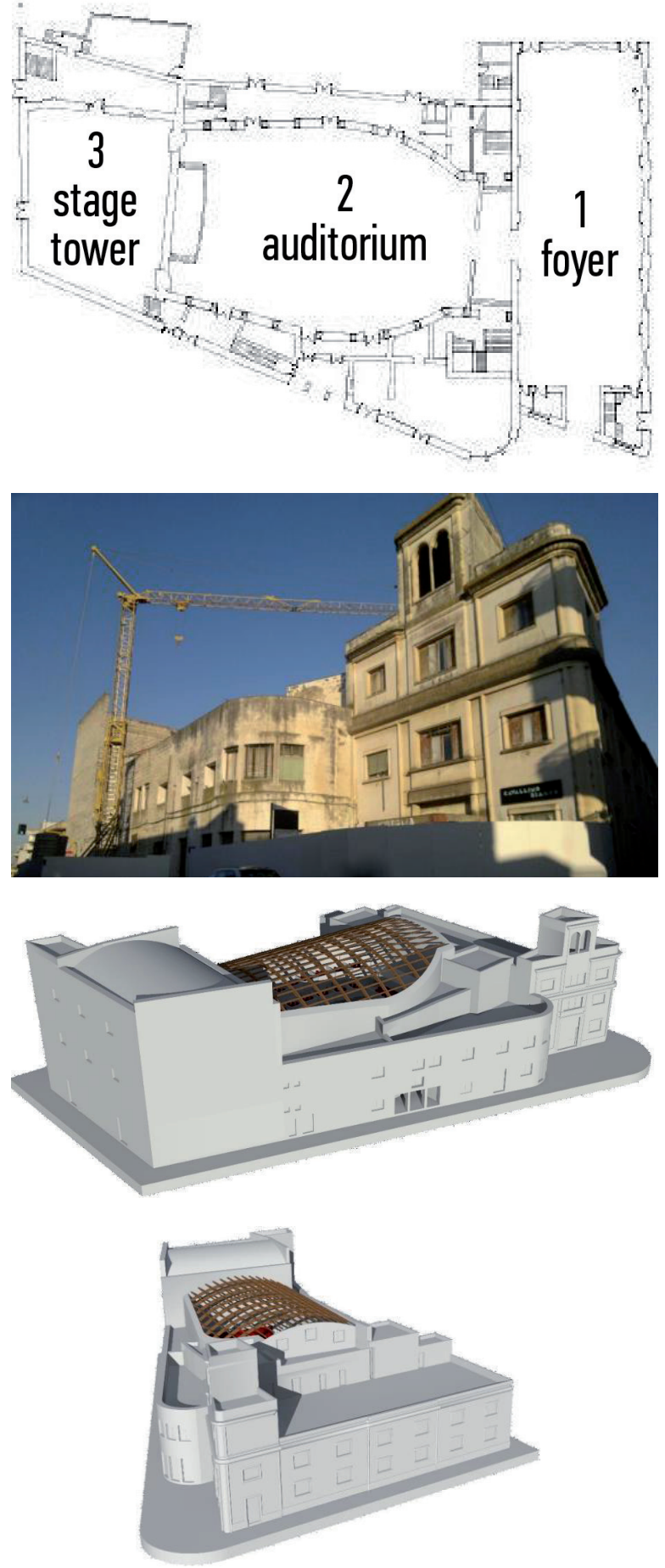

Figure 1. General layout of the building. 
With regard to construction history and the conduct of the buildings over the years by different owners, the relevant facts can be summarized in the following remarks:

- 1945-47: the foyer was built and used as winery.

- 1947: the constriction of the auditorium and the tower starts.

- 3 February 1949: inauguration of the theater with a performance of the opera "il Rigoletto".

- "70s: crisis of the theatre activity.

- 2000: end of the theatre activity.

- 2002: the local municipality bought the theatre.

- 2003: interventions against fire attack according with the Italian Code.

- 2006: ideas competition on the auditorium, involved 23 teams of designers.

- 2013-2015: Structural assessment and seismic upgrade funded by the municipality and government, accompanied by a re-styling of the theater which is need to be given back to the citizens and the entire regional community.

From a structural point of view masonry walls, in some regions are interrupted by the presence of concrete columns, to constitute a mixed structure, in which the horizontal parts are formed by reinforced concrete plain or curved elements. Although it is possible to individuate two moments that have marked the realization of the theatre (the foyer built in 1947 and the remaining bodies around 1948-49), all the three main bodies are structurally connected and clamped together. In particular, the foyer has joined to the auditorium by concrete beams that are embedded in the masonry body of the foyer, while the stage tower and the auditorium are made in continuity, with the same construction techniques and materials. The section views are reported in figure 2.

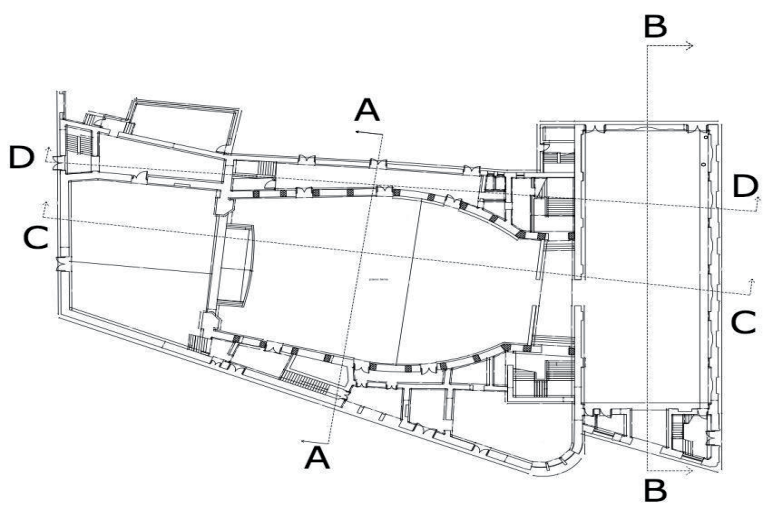

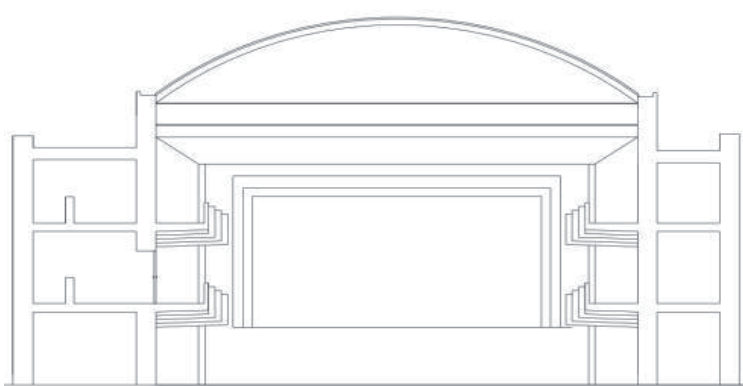
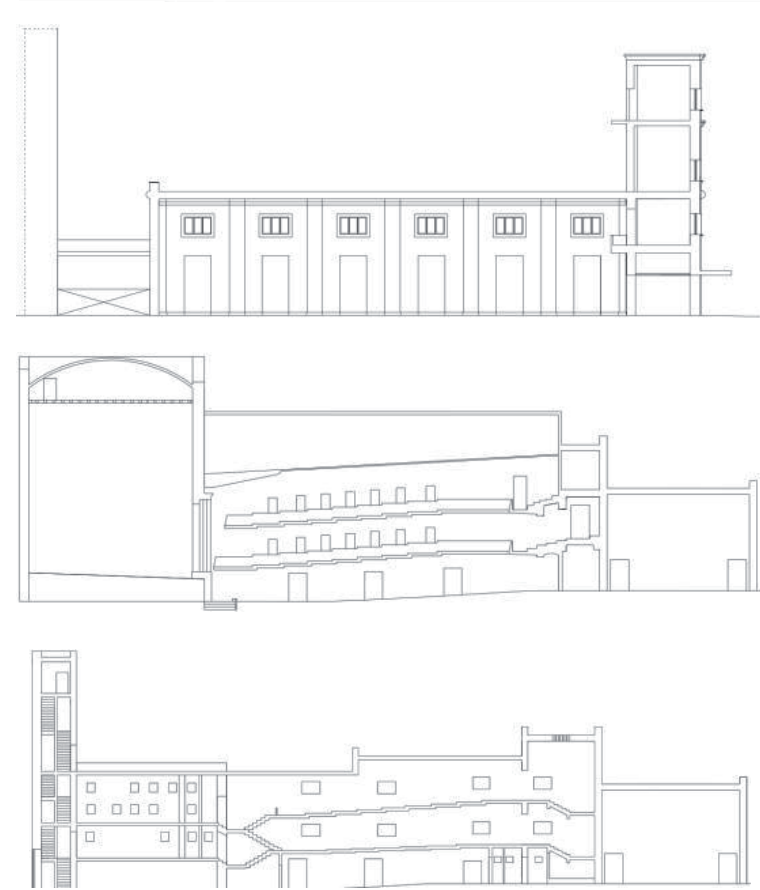

Figure 2. Section views.

The vertical structures of all the three bodies are constituted by load-bearing masonry, with the exception of the body 2 in which is present a loadbearing structure constituted by mixed masonry walls and vertical concrete structures. The walls have a solid cross-section with a thickness from $50 \mathrm{~cm}$ to $95 \mathrm{~cm}$. The masonry consists of limestone blocks with sharp cut; the stone is a soft limestone which is typical of the region of construction. Masonry has joints mad by a poor hydraulic binder without cement-based materials. The body 1 has a plan roof with a single span of approx. 12 meters realized with structure made by ribbed parallel reinforced concrete beams cast on site. The body 2 and the body 3 have a covering of great span with the geometry of a parabolic arch formed by a floor equal to the total thickness $\mathrm{H}=250 \mathrm{~mm}$, including the $50 \mathrm{~mm}$ thickness of the full slab. This structure presents iron tendons made by tubular profiles joined at the middle by a screw for the resumption of the pre-stress, even if they were found without tensile stress inside. The curved roof is connected to the walls 
by means of a concrete capping beam with curve axis, which follows the plan direction, which is also curved. This cover, that was heavy and presented large regions of carbonated concrete and corroded steel, was decided to be replaced with a light curved roof made by glulam timber, after the reconstruction of the reinforced concrete capping beam. The body 2 has also internal plain regions at a lower altitude than the curved roof as seen in figure 3. They form the roof of the side aisles and escape routes; these floors are made entirely of solid blocks of tuff and $150 \mathrm{~mm}$ wide reinforced concrete ribs cast on site placed at a distance of $800 \mathrm{~mm}$.
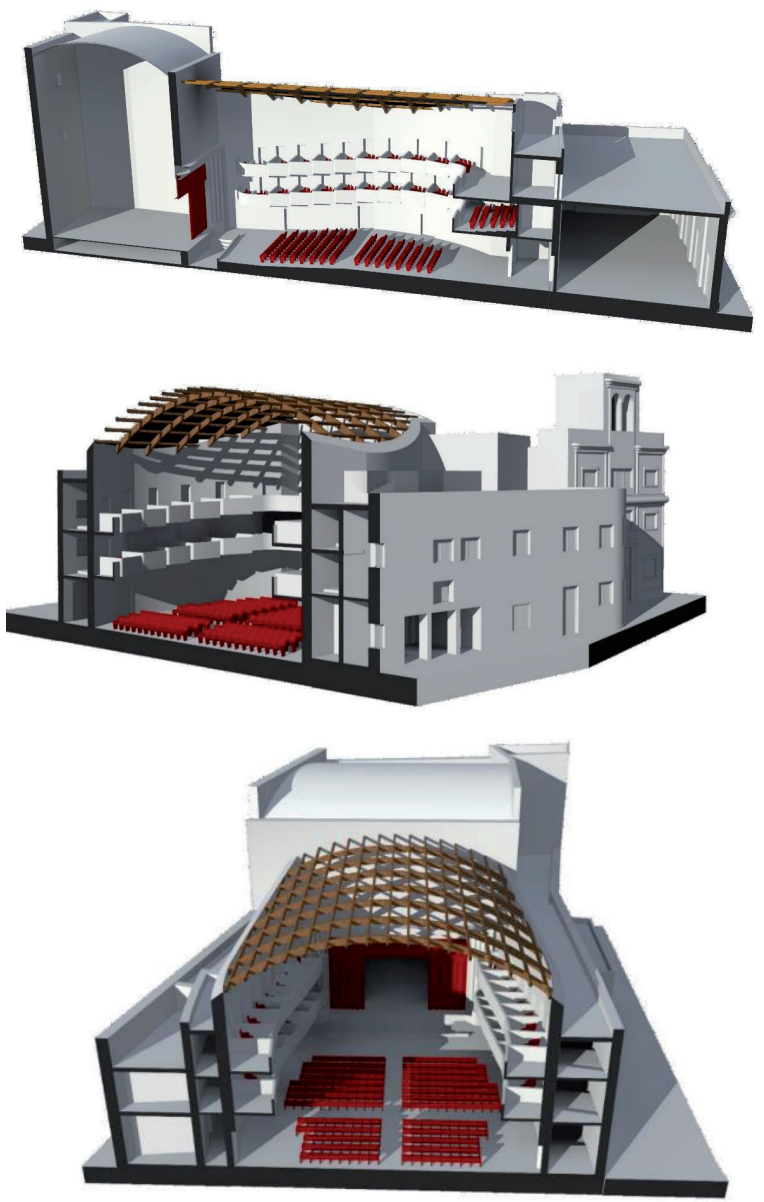

Figure 3. Indoor views of the building (3D model).

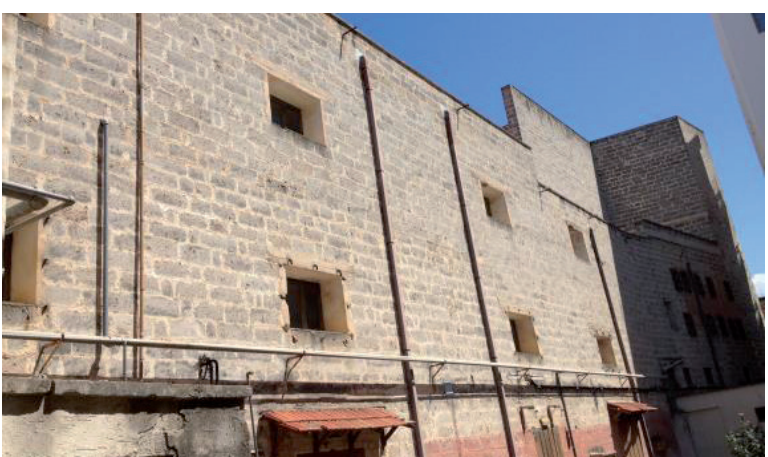

Figure 4. Outdoors view of the building. Detail of the masonry texture.
Thus the first seismic upgrade strategy consisted of building a lighter roof in the theatre auditorium even if this needed to be supported by analytical prediction. In fact the presence of a lighter roof could be accompanied by two opposite effects: the first is related to a strong reduction of excited mass (which is a positive effect); the second is represented by a reduction in axial forces acting on masonry walls, that may cause lower ultimate load for out-of plane rotation mechanisms. The computation of these effects led to a decision in favour of the timber structure.

MODAL ANALYSIS

The dynamic modal analysis was run in order to provide safety factors or deficiencies related to the possible rupture of walls, rigid connections, foundations or ground. This tool, however, cannot be used as the unique method to individuate seismic vulnerability of existing masonry structures. As known, the uncertainties in the modeling of masonry structures are considerable and it is therefore good practice to reach an evaluation through the correlation of the different analyses, also because rigid collapses of structural masonry have been extensively recognized from past earthquakes. Below it is given a detailed graphical representation of the operated discretization in the finite element model (figure 5).
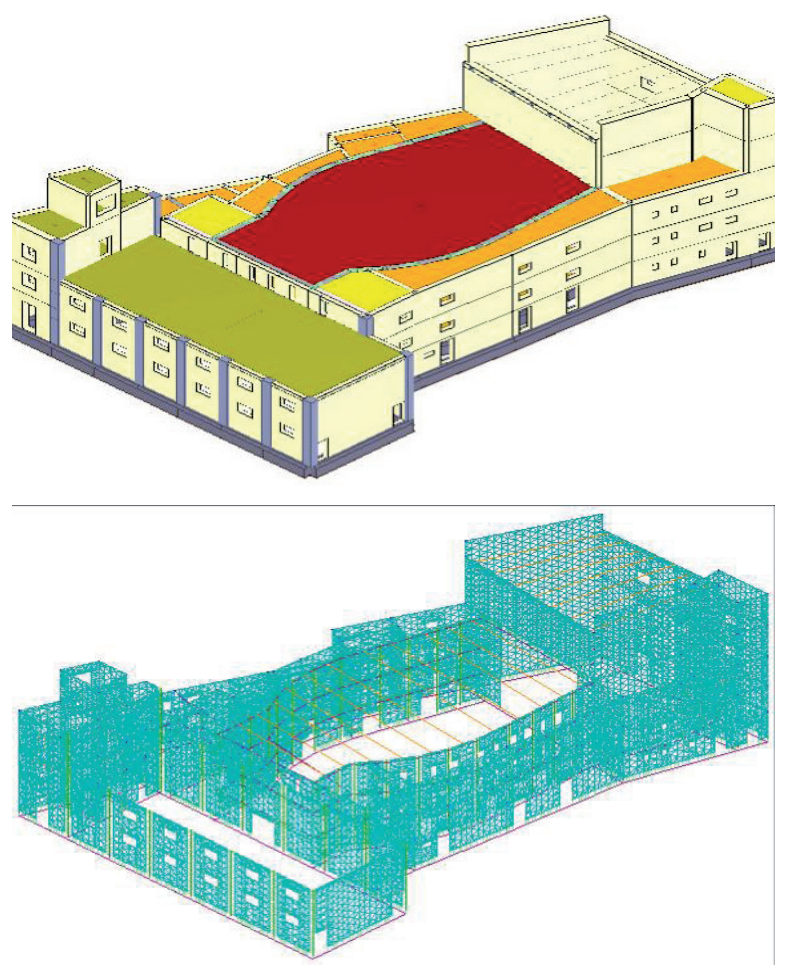

Figure 5. Finite element solid model. 
Columns and beams were considered as beam elements. The nodes are placed on the vertical axis of the columns, at the extrados of the highest beam that connects them. The masonry walls are modeled through triangular or quadrangular shell elements. figure 6 shows some of the results of the modal analysis in terms of displacement of the structural bodies. The displacements of the body 1 , the foyer, appear to be negligible and are not reported.

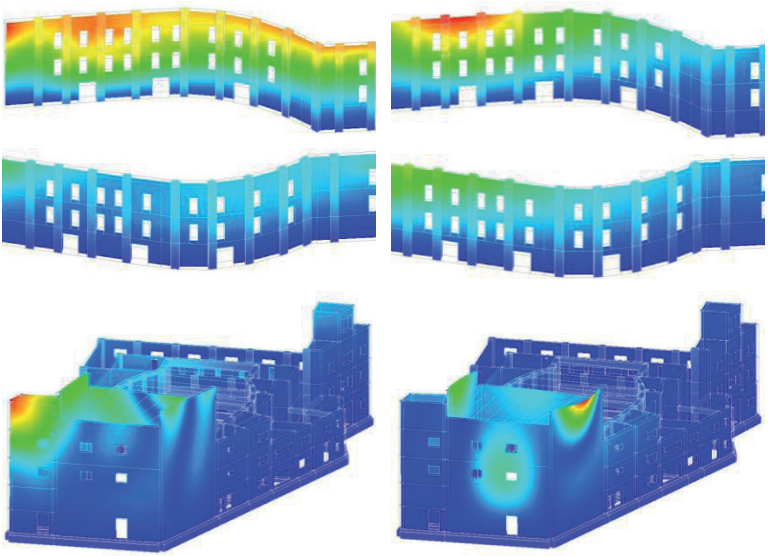

Figure 6. Modal analysis output (displacements).

The main modes of vibration were considered; excluding the structural behaviour which involve insignificant percentage of the total mass. The safety of masonry walls was controlled respect to rupture due to shear, normal eccentric forces, sliding, crushing under compression; as same as safety of concrete elements was checked against flexural/shear forces and eccentric normal forces. Foundation settlements and ground limit state were also checked by using the results of the global analysis. The finite element maps helped also to individuate possible kinematic mechanisms that needed to be identified and studied in order to assess the real seismic vulnerability of the building. In the following the mechanisms that were highlighted as the most compromising for the building will be illustrated and analyzed.

KINEMATIC ANALYSIS OF MASONRY WALLS

The kinematic limit analysis (KLA) is a wellknown evaluation strategy able to assess a dimensionless index of seismic vulnerability of a structure or part of it. This is important in order to list many different collapse mechanisms and catch out the most dangerous one. The KLA is based on the principle of virtual work and consists in relating the overturn moment (due to the equivalent inertia force applied in the cen- troid of the element and horizontally oriented) with respect to the resistant moment (due to the gravity loads). The moments are generally calculated referring to one of the centre of rotation of the analysed mechanism. The fundamental hypothesis of this procedure is to assume as unlimited the compressive strength of the masonry while the main advantage is that it provides accurate prediction by knowing just the geometry of the structure and the weight of the materials. Two approaches maybe used by designers, which are a linear one and a non linear one, the first is quick but less accurate, the second requires different steps of analyses but it is more accurate than the first. The linear analysis offers the index corresponding to the inertia force (related to the peak ground acceleration), which is responsible of the beginning of the collapse; while the notlinear analysis does not present difference from the computational point of view but it is simply repeated several times by updating the deformed configurations and acting forces step by step. In this case a capacity curve in term of horizontal displacement is obtained which is compared with an assumed limit displacement which is the ultimate value compatible with the equilibrium of the structure.

The linear method allows obtaining the collapse mechanism energetically more likely, in fact, the kinematic which requires the minimum of the ground acceleration to start is the ultimate equilibrium stage of the structures. According to [1] the combination of load used is the seismic combination, are shown in Eq. (1):

$$
E+G_{1}+G_{2}+P+\psi_{21} Q_{K 1}+\psi_{22} Q_{K 2}
$$

In which $\mathrm{E}$ is the seismic force, $\mathrm{C}$ are the dead loads, $\mathrm{Q}$ are the live loads. The calculation of the load multiplier $\alpha 0$ which involves the activation of the mechanism (damage limit state) by applying the principle of virtual work, in terms of displacements is based on virtual works theorem. By equating the total work performed by the external and internal forces applied to the system in correspondence of the virtual motion the Eq. (2) is shown:

$0{ }_{i=l}^{n} P_{i x, i}+{ }_{j=n+1}^{n+m} P_{j x, j} \div{ }_{i=l}^{n} P_{i y . i}+{ }_{h=l}^{o} F_{h h}=L_{f i}(2)$

where:

- $\mathrm{n}$ is the number of all the weight forces applied at the various blocks of the kinematic chain 
- $m$ is the number of weight forces not directly imposed on the blocks whose masses, for seismic action effect, generate horizontal forces on the elements of the kinematic chain, as it does not effectively transmitted to other parts of the building

- 0 is the number of external forces, not associated with masses, applied to different block

- Pi is the generic weight force applied (dead loads of the block, applied in its centre of gravity)

- $\mathrm{Pj}$ is the generic weight force, not directly applied on the blocks, whose mass, for seismic action effect, it generates a horizontal force on the elements of the kinematic chain, as it does not effectively transmitted to other parts of the building

- $x, i$ is the displacement of the horizontal virtual point of application of the $i^{-}$ weight Pi, assuming as positive toward the one associated to the direction in which acts the seismic action which activates the mechanism

- $x, j$ is the displacement of the horizontal virtual point of application $\mathrm{j}$-weight $\mathrm{Pj}$, assuming as positive toward the one associated to the direction in which acts the seismic action which activates the mechanism;

- ${ }_{y, \mathrm{i}}$ is the displacement of the vertical virtual point of application of the $\mathrm{i}$-weight $\mathrm{Pi}$, assumed positive if upwards

- $F_{h}$ is the generic eternal force (absolute value), applied to a block

- $h$ is the displacement of the virtual point where the h-external force is applied

- $\mathrm{L}_{\mathrm{fi}}$ is the work of the internal forces

The calculation of the participating mass in the mechanism $M^{*}$ considering the virtual displacements of the points of application of the different weights, associated with the mechanism, have a shape similar to the modal analysis as reported in Eq. (3).

$$
M *=\frac{{ }_{i=l}^{n+m} P_{i}{ }_{x, i} \div{ }^{2}}{g x{ }_{i=l}^{n+m} P_{i}{ }_{x, i}^{2}}
$$

The calculation of the eccentricity of the fraction of the participating mass of the structure is shown in Eq. (4).

$$
e^{*}=\frac{g \times M^{*}}{{ }^{n-n} P_{i}}
$$

Finally the calculation of the spectral acceleration of activation of the mechanism ${ }_{0}^{*}$ is reported in Eq. (5).

$$
{ }_{0}^{*}=\frac{0{ }_{i=l}^{n+m} P_{i}}{M^{*}}
$$

The benchmark of the analysis is the acceleration of the design spectrum ${ }_{\mathrm{d}}$ as clear in Eq as clear in Eq. (6).

$$
{ }_{d}=\frac{a_{g} S}{q} 1+1,5 \frac{Z}{H}+
$$

where:

- $S$ is the factor that takes into account the stratigraphic profile of the foundation soil;

- $a_{q}$ is the maximum horizontal acceleration of the ground;

- $q$ is the structure factor that is assumed in the design phase equal to 2 ;

- $Z$ is the quota of application of the seismic action;

- $\mathrm{H}$ is the total height of the building.

The non linear analysis repeats in several steps the linear analysis of the rotated configurations until the centroid of the structure overpass the footprint area of the base, by leading to a real capacity curve.

In this case, the benchmark is the spectral displacement $\mathrm{d}^{*}$ assumed as in Eq. (7).

$$
d^{*}=d_{K} \frac{{ }_{i=l}^{n} P_{i x, i}^{2}}{{ }_{x, k}^{n} P_{i=l} X_{x, i}}
$$

where:

- $d_{k}$ is the horizontal displacement of the assumed control point.

There are several possible mechanisms of collapse, so it is up to the designer identify, analyze its dangers and prepare an eventual intervention of seismic upgrading. In figure 7 the most vulnerable mechanism is highlighted, which is represented by the possible simply overturning of the back wall of the stage tower which appears the easiest to happen because it is amenable to a static scheme of a huge cantilever of $75 \mathrm{~cm}$ thickness and $21 \mathrm{~m}$ height. 
In this case the analysis was conducted with reference to all the local mechanisms that can be activated by the seismic acceleration in the considered wall. The kinematic analysis was performed as linear and non-linear. Once the seismic vulnerability was quantified in terms of acceleration and displacement, a strengthening system was designed. The seismic upgrade was evaluated by the comparison with respect to the un-reinforced state of the construction. The main results of the analysis conducted on the evaluation of seismic vulnerability are reported in table 1 with reference to all the possible local mechanisms. It is shown how the linear analysis may be more conservative with respect the non-linear one. As clear, the simple overturning of the unreinforced walls of the tower represents the major weakness. The design of a strengthening device was necessary. The installation of 4 ropes made of CFRP produced significant improvement in terms of capacity of the structure to less rotate and absorb higher ground acceleration. The choice of composite materials allowed this type of innovative technique, by guaranteeing a high durability, speed of installation and safe operations in elevation.

In figure 10 the capacity curves of the unreinforced and reinforced wall (URM and RM respectively) are compared. The centroid of the wall was chosen as control point. It is evident the different shape of the two curves: linear or pseudo linear for the unreinforced wall and segmented for the reinforced one. In both cases the first point of the curve, relate to the 0 displacement, is calculated as in the linear analysis because the initial value of ${ }_{0}^{*}$ represents the minimum acceleration required to make the overturning start.

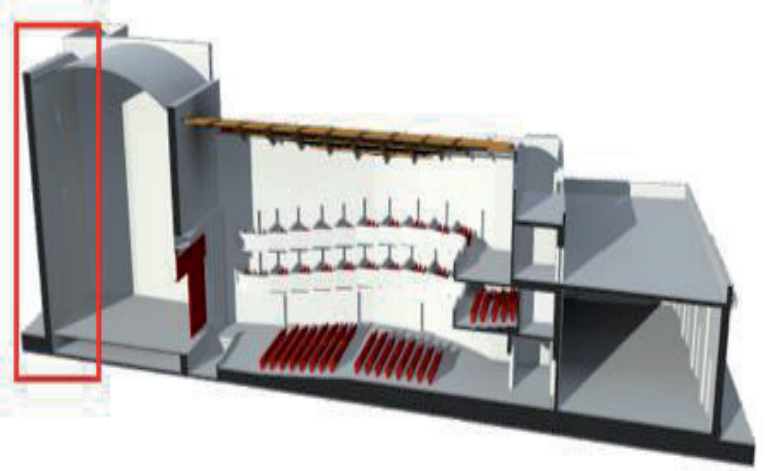

Figure 7. Individuation of the possible most vulnerable element of the structure.
TABLE 1. SUMMARY OF THE LINEAR AND NOT LINEAR ANALYSIS FOR THE UNREINFORCED AND REINFORCED MASONRY

\begin{tabular}{|c|c|c|c|c|c|c|}
\hline \multirow[t]{2}{*}{ Kinematics } & \multicolumn{3}{|c|}{ Unreinforced } & \multicolumn{3}{|c|}{ Reinforced } \\
\hline & $\begin{array}{r}\text { * } \\
0 \\
{[g]}\end{array}$ & $\begin{array}{r}d \\
{[g]}\end{array}$ & $\begin{array}{r}\% \\
\text { safety }\end{array}$ & $\begin{array}{r}* \\
0 \\
{[\mathrm{~g}]}\end{array}$ & & $\begin{array}{r}\% \\
\text { safety }\end{array}$ \\
\hline \multirow{6}{*}{$\begin{array}{l}\text { Simple overturning } \\
\text { Composed overturning } \\
\text { Corner overturning } \\
\text { hinge } 5 \mathrm{~m} \text { high Corner } \\
\text { overturning hinge } 10 \mathrm{~m} \\
\text { high } \\
\text { Overturning vertical } \\
\text { bending }\end{array}$} & 0,032 & 0,083 & -61 & 0,071 & 0,083 & 6 \\
\hline & 0,132 & 0,091 & 44 & 0,159 & 0,091 & 74 \\
\hline & 0,189 & 0,101 & 87 & 0,230 & 0,099 & 133 \\
\hline & 0,125 & 0,106 & 18 & 0,161 & 0,099 & 62 \\
\hline & 0,064 & 0,089 & -29 & - & - & - \\
\hline & $\mathrm{d}[\mathrm{cm}]$ & $\begin{array}{r}\Delta \mathrm{d} \\
\text { (Ts) } \\
{[\mathrm{cm}]}\end{array}$ & $\begin{array}{r}\% \\
\text { safety }\end{array}$ & $\begin{array}{r}\text { * } \\
{[\mathrm{cm}]}\end{array}$ & $\begin{array}{r}\Delta \mathrm{d} \\
(\mathrm{Ts}) \\
{[\mathrm{cm}]}\end{array}$ & $\begin{array}{r}\% \\
\text { safety }\end{array}$ \\
\hline \multirow{5}{*}{$\begin{array}{l}\text { Simple overturning } \\
\text { Composed overturning } \\
\text { Corner overturning } \\
\text { hinge } 5 \mathrm{~m} \text { high Corner } \\
\text { overturning hinge } 10 \mathrm{~m} \\
\text { high } \\
\text { Overturning vertical } \\
\text { bending }\end{array}$} & 14,7 & 10,7 & 37 & 34,2 & 10,7 & 221 \\
\hline & 66,8 & 10,9 & 512 & 66,8 & 10,9 & 512 \\
\hline & 106,1 & 12,0 & 787 & 116,2 & 12,0 & 872 \\
\hline & 69,1 & 12,5 & 454 & 78,3 & 12,5 & 528 \\
\hline & 12,0 & 10,7 & 13 & - & - & - \\
\hline
\end{tabular}

The importance of the FRP wire installation is immediately underlined by this value, which appears three times more for the RM with respect the URM. In a first range of displacement, eligible between 0 and about $30 \mathrm{~cm}$, different behaviour is observable. The URM required gradually less acceleration with the increase of the rotation because the most is the deformation the most is the vulnerability. On the other hand, the RM shows linear proportion between the acceleration and the displacement due to the passive confinement action, which increases in relationship with the displacement that stresses the ropes. This trend continues until a certain value after that the inclination change. This critical point corresponds to the failure of the top rope. The wall overturning continues causing the failure of the remaining FRP ropes until the ultimate displacement is reached and the kinematics bring the structure to collapse. The maximum horizontal displacement the centroid of the wall can support was at least six times more for the RM with respect the URM.

The comparison in term of energy is also representative because the area underlying the capacity curve of the URM is entirely included in the area underlying the RM ones, and it is of relevance since these areas represent the absorbed energy under seismic 
forces. The reinforced masonry can dissipate more seismic energy due to the increased ductility that the FRP provides to the URM in terms of possible rotations. In table 2 the safety of the structure is indicated in percentage relating the supply and demand in term of displacement. In both case the safety level was ensured but the effectiveness of the strengthening is pointed out by the kinematic analysis that establishes how the wall can support stronger seismic events.

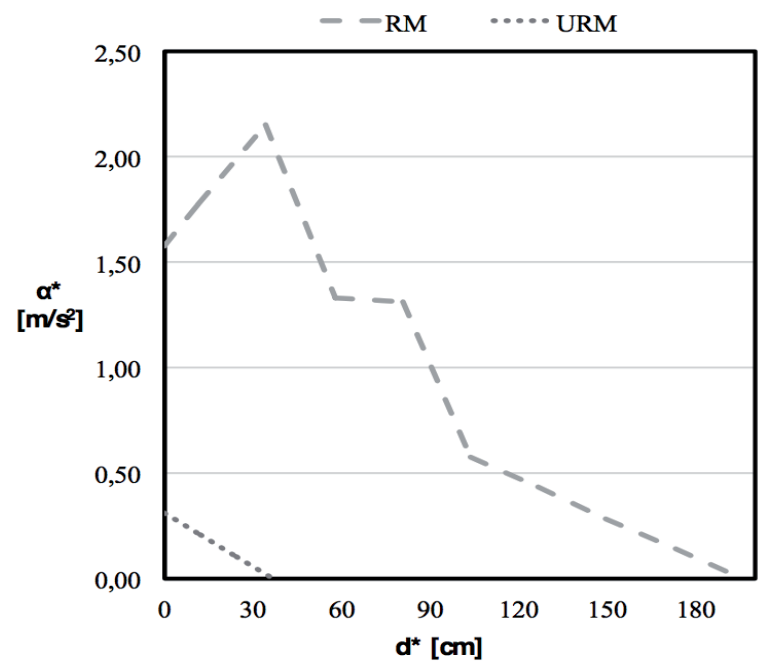

Figure 8. Capacity curve of the Un-Reinforced Masonry (URM) and of the Reinforced Masonry (RM)

Nonlinear analysis results to be a tool able to provide more detailed feedback in the identification of the seismic vulnerability of the system. The linear analysis is still a valuable tool, and more conservative, which must be used in initial analysis when the importance of the structure requires a non-linear analysis for deeper study. Another important as pect is that with the non-linear analysis the evolution of the mechanism may be observed in detail.

SEISMIC UPGRADING tainment of the walls, and then to exert an action that opposes to the kinematic mechanism that can be set up as a result of the action of the inertial forces performing in the perpendicular plane and generated by seismic event. According to [2]:

the strengthening process needs also to minimise the impact on the historical value of the building. The design of the reinforcement is based on the knowledge of the load story of the structure as well as the degradation and

the deformation; the choose of the strengthening technique must privilege the most reversible one, if necessary, it can be removed and replaced without leaving important signs.

The geometry of the structure make the application of the traditional system of the steel ties time consuming and dangerous for the team worker which have to move and install it. All this disadvantages are solved by using CFRP flexible wires, which are easy to handle due to the negligible self-weight but keeping a high level of tension strength. So FRP materials were used, and properties of the wire-strengthening system are reported in table 2.

TABLE 2. ROPE DETAIL

\begin{tabular}{l|r}
\hline FAILURE STRESS [MPA] & 4800 \\
\hline FAILURE LOAD [KN] & 100 \\
\hline NET AREA [MM2] & 22 \\
LENGTH [M] & 44,5 \\
\hline E [MPA] & 240000 \\
PRE STRESS [KN] & 20 \\
\hline PRE ELONGATION [CM] & 16,9 \\
\hline FAILURE ELONGATION [CM] & 84,3
\end{tabular}

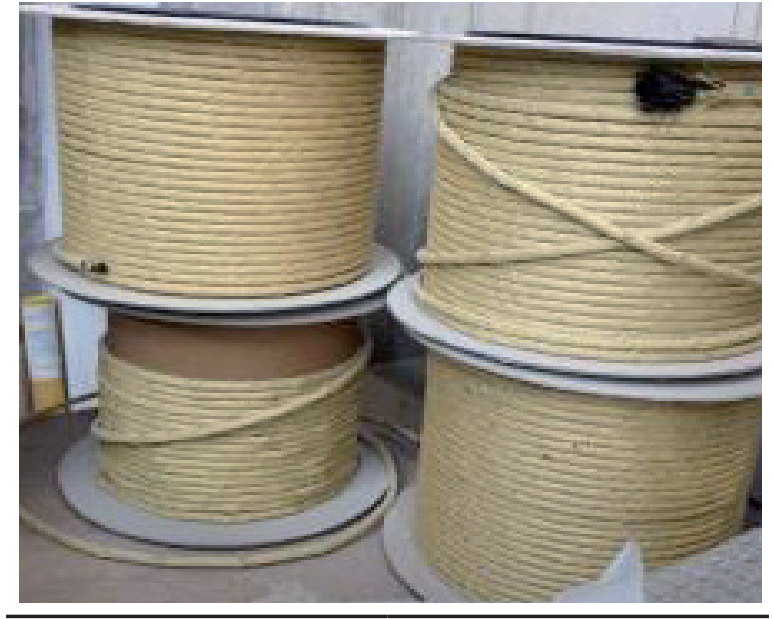

FRP material remains elastic until rupture so the efficiency of using this material increase with the increase of the deformation of the element which the FRP is acted to counteract. Carbon fibres are not prone to creep as same as steel that is commonly used for tendons in masonry, and they not require protection against galvanic corrosion. A $40 \mathrm{kN}$ pre-stress force was designed in order to make the wires to perform as active ties from the beginning. The intervention regards the walls of the tower, which appear vulnerable due to its high slenderness (see figure 9). 


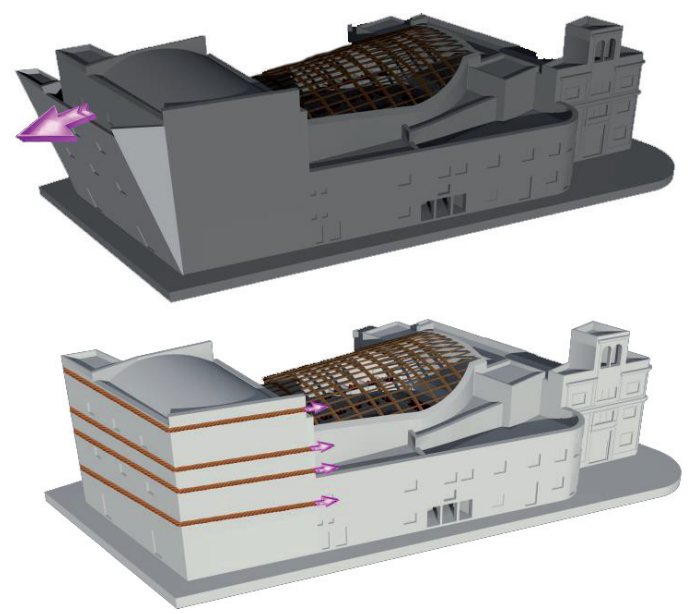

Figure 9. Overturning of the walls of the tower (up) and strengthening action (down).

The strengthening process is listed in the following and is illustrated in figure 10:

- Cutting the surface in order to derive an engraving depth of about $25 \mathrm{~mm}$ to allow the housing of the cable and the subsequent adhesion by means of epoxy paste.

- Cleaning of the surface obtained after cutting by dry blowing.

- Laying of a layer of epoxy primer with low viscosity on the wall surface machined in order to avoid additional dusting of stone parts and, at the same time, to create a substrate chemically affine to the next thixotropic resin bonding.

- Housing of the ends of the rope reinforcement in the sleeves metal terminals that have to be clean, perfectly dry and free of any residue of mechanical processing.

- Bonding of the sleeves through structural epoxy resins with low viscosity and rapid curing.

- Manual stringing of the FRP rope in the wall incision reported in point 1 .

- Positioning of the anchoring plates by means of temporary works such as to prevent the fall of the same.

- FRP ropes pre-stress.

- Bonding of the stretched cable to the wall by injecting epoxy thixotropic and subsequent regularization of surface by manual means (spatula).

- Restoring the finish wall by mortar made of powder of the same stone.

- Lying of any plaster and finishing layers.

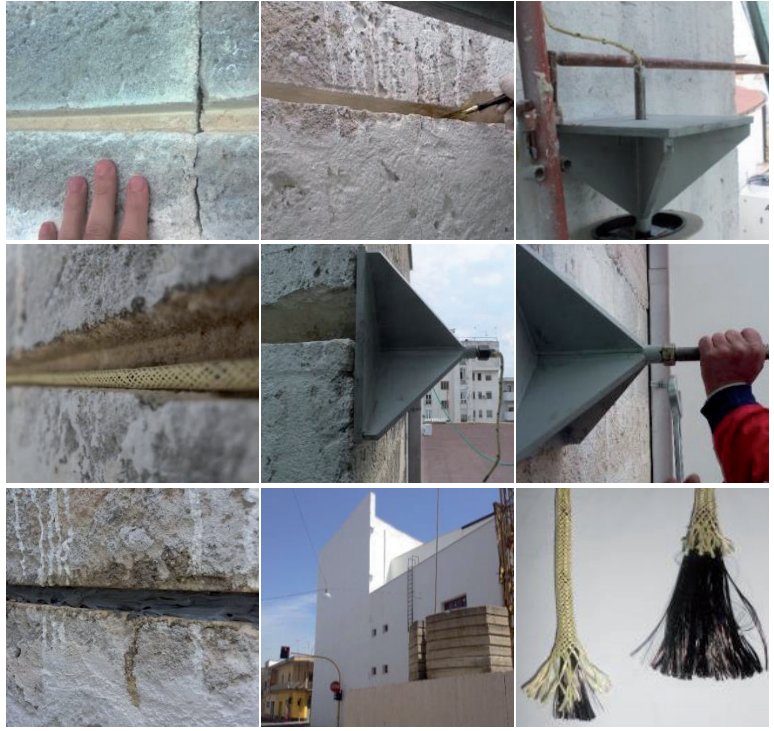

Figure 10. Process steps (1-11) and detail of the CFRP wire.

CASE 2 - DESCRIPTION OF THE BUILDING

The second case study is related at the same time to a seismic upgrade and to a structural strengthening of an ancient masonry building, which had several cracks and sliding surfaces at the interfaces between the masonry blocks. The building was fabricated in different steps, starting from 1650, and it is now formed by two storeys which are used as civil buildings. This is an important factor since the different ages of construction was one of the causes of the cracks due to inadequate construction details during the assemblage of the new masonry upon the existing one.

The figure 11 shows by numbering the different construction phases; the different steps of construction started in 1650 and ended in 1836 according to the collected information.
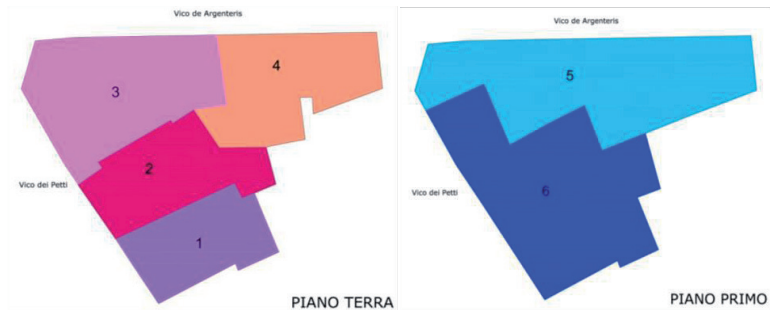

Figure 11. Masonry building - construction steps.

The construction materials that was used is a soft limestone that was tested by extracting $\mathrm{cu}^{-}$ bic and cylindrical specimens from the blocks of the masonry walls. The vertical walls were built with double walls connected with transverse stone blocks, the roofs were built with vaults that push their thrusts on the external walls or other adjacent arches. 
The lack of connection between the different construction blocks and the presence of the thrusts, in conjunction with settlements that were present along the centuries, generated cracks along the masonry walls that needed to be analyzed and contained. Another problem was also discovered in the vault at ground floor in apartment 2 (see figure 11), in which the mortar between joints was reduced to dust, and thrusts of the vaults was reduced, by causing extensive cracks along the vault surface.

In figure 12 the cracks in the mentioned vaults are sketched. In figure 13 the cracks in the external walls are illustrated.
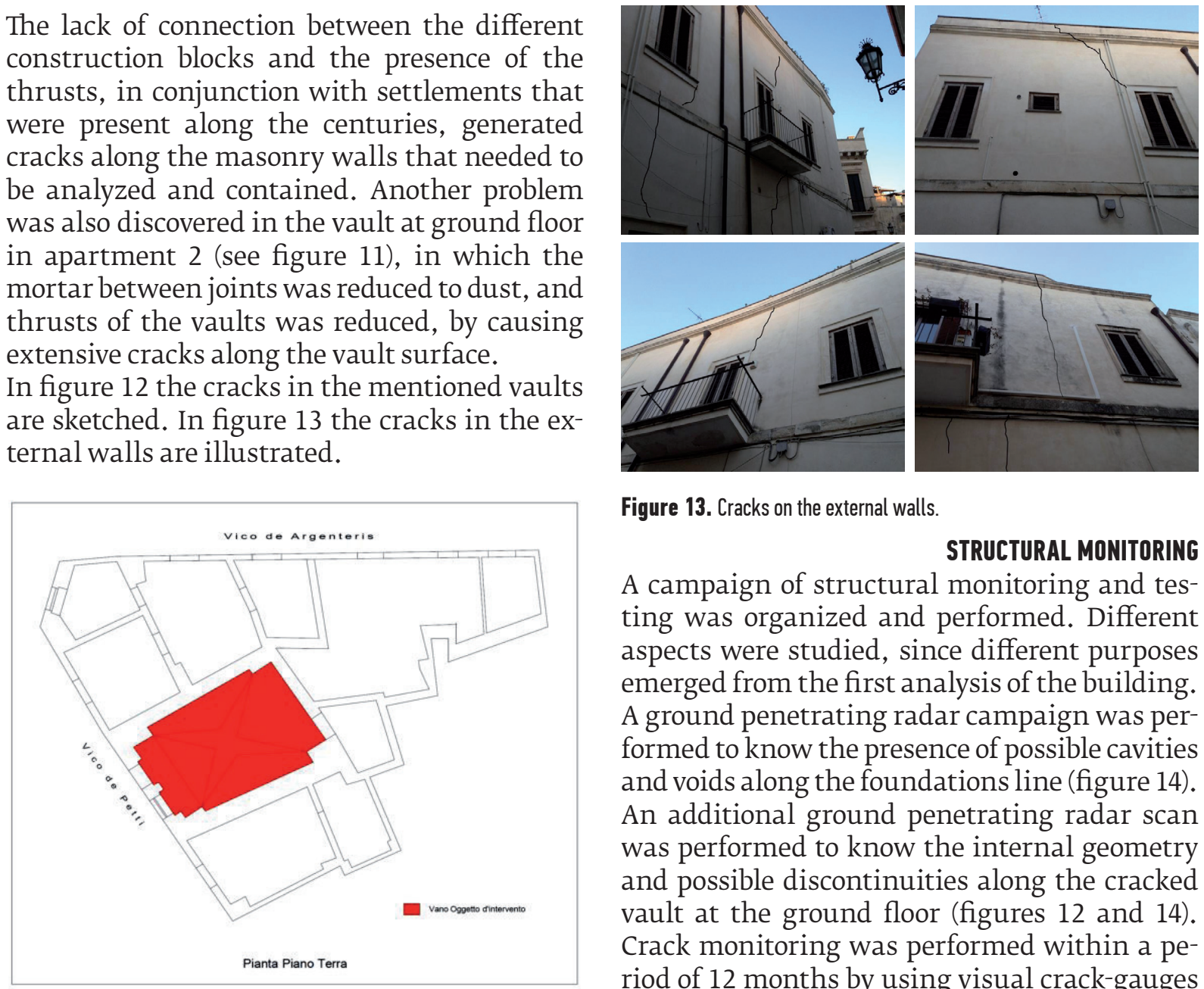

Figure 13. Cracks on the external walls.

STRUCTURAL MONITORING

A campaign of structural monitoring and testing was organized and performed. Different aspects were studied, since different purposes emerged from the first analysis of the building. A ground penetrating radar campaign was performed to know the presence of possible cavities and voids along the foundations line (figure 14). An additional ground penetrating radar scan was performed to know the internal geometry and possible discontinuities along the cracked vault at the ground floor (figures 12 and 14). Crack monitoring was performed within a period of 12 months by using visual crack-gauges (figure 15) and a digital microscopy device with magnification factor up to $250 \mathrm{x}$ (figure 16).
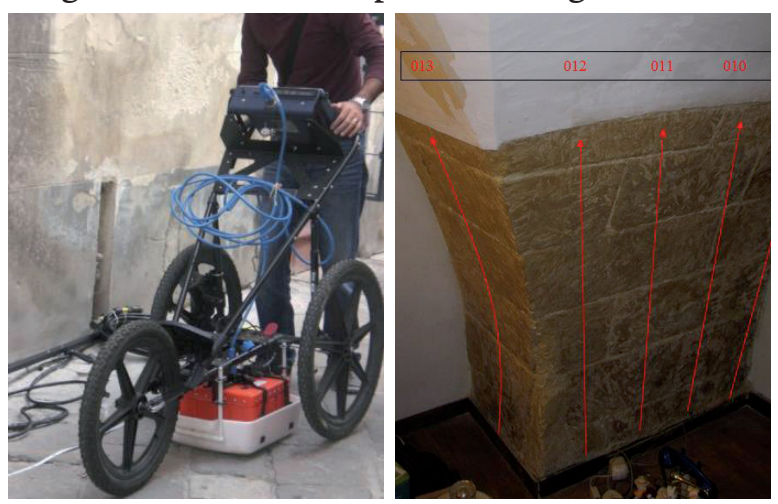

Figure 14. Ground penetrating radar scan: foundation line; vault.

Figure 12. Cracks in the vault at ground floor.

By simulating the behaviour of the walls under seismic horizontal actions, the external walls were inadequate to carry the lateral forces of the earthquake in addition to the horizontal thrusts of the vaults. Thus a strengthening program was designed, after a program of structural monitoring that allowed to know the geometry, the materials and the structural health of the building.

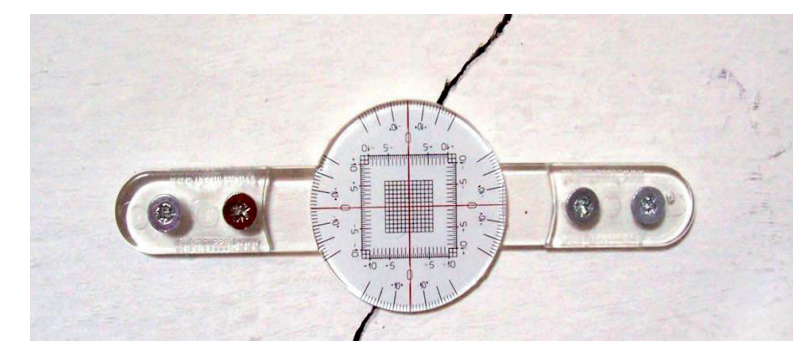

Figure 15. Visual crack-gauge. 


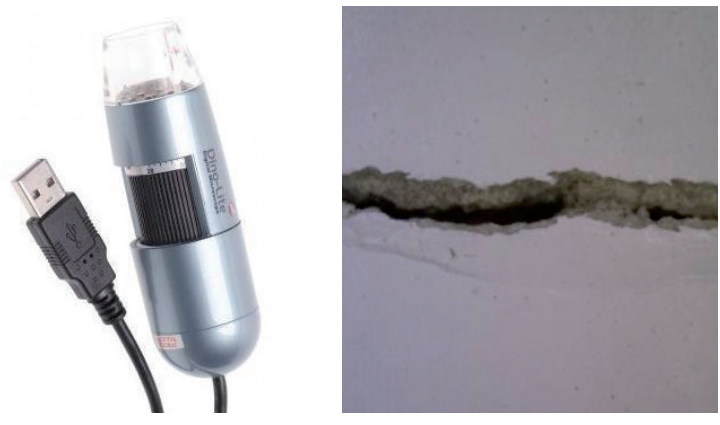

Figure 16. Digital microscopy lens - typical crack image $60 \mathrm{x}$.

In order to estimate the mechanical properties of the masonry five blocks were extracted and cubic specimens with dimensions of $100 \times 100 \times 100 \mathrm{~mm}$ were cut, in addition to cylindrical specimens with a diameter of $100 \mathrm{~mm}$ and height of $100 \mathrm{~mm}$. The average compressive strength of the stone resulted 5.5 $\mathrm{MPa}$. The mortar was a weak hydraulic mortar with thin joints of about $4 \mathrm{~mm}$. The compressive strength of the masonry was estimated to be about 2.3 MPa according to the Italian technical code. Due to the results of the structural monitoring process and material testing the strengthening strategy was decided. The cracking demonstrated to be into a decreasing branch since the width of the cracks was quite stable. The foundation presented areas of irregularity due to pipes and other engineering modifications that were made in the last decades. For this aspect the municipality had to proceed at restoring some structural parts of the two adjacent roads. The cracked vault presented discontinuities due to the degradation of the mortar. Overloads were present due to successive manipulation of the pavement at the terrace floor, since three paving layers were encountered. Two of them were dismembered and removed.

\section{STRUCTURAL AND SEISMIC STRENGTHENING}

Two main aspects were considered in calibrating the strengthening process that had to restore the structural deficiencies and to upgrade the building in order to resist to seismic forces according to the new technical codes. The first is related to the local strengthening need of the cracked vault, the second was related to the global behaviour of the building. The vault was strengthened in two phases, the first one was aimed at repointing the mortar joints that were empty due to the mortar degradation, the second one was aimed at FRP-strengthening of the intrados to reduce the lateral thrusts.
A cementitious mortar was injected in order to create a renewed stiffness of the vault, controlled viscosity and special valves were use to avoid the mortar to come out form the masonry shell. This strengthening phase is illustrated in figure 17.

After theinjection of the mortar a monolithic vaulted structure was achieved, allowing to increase the stiffness and to develop the compression forces between the masonry blocks that were disconnected due to the loss of the mortar joints. Then a glass fiber net was bonded with mechanical anchorages along the intrados of the vault. Alkali resistant glass fibers were used to increase the durability of the materials, the dry fiber mesh $0 / 90^{\circ}$ had a density of $220 \mathrm{~g} / \mathrm{m}^{2}$. A cementitious mortar was used as matrix and bonding agent, thus an FRCM (Fiber Reinforced Cementitious Mortar) system was installed, as visible in figure 18.
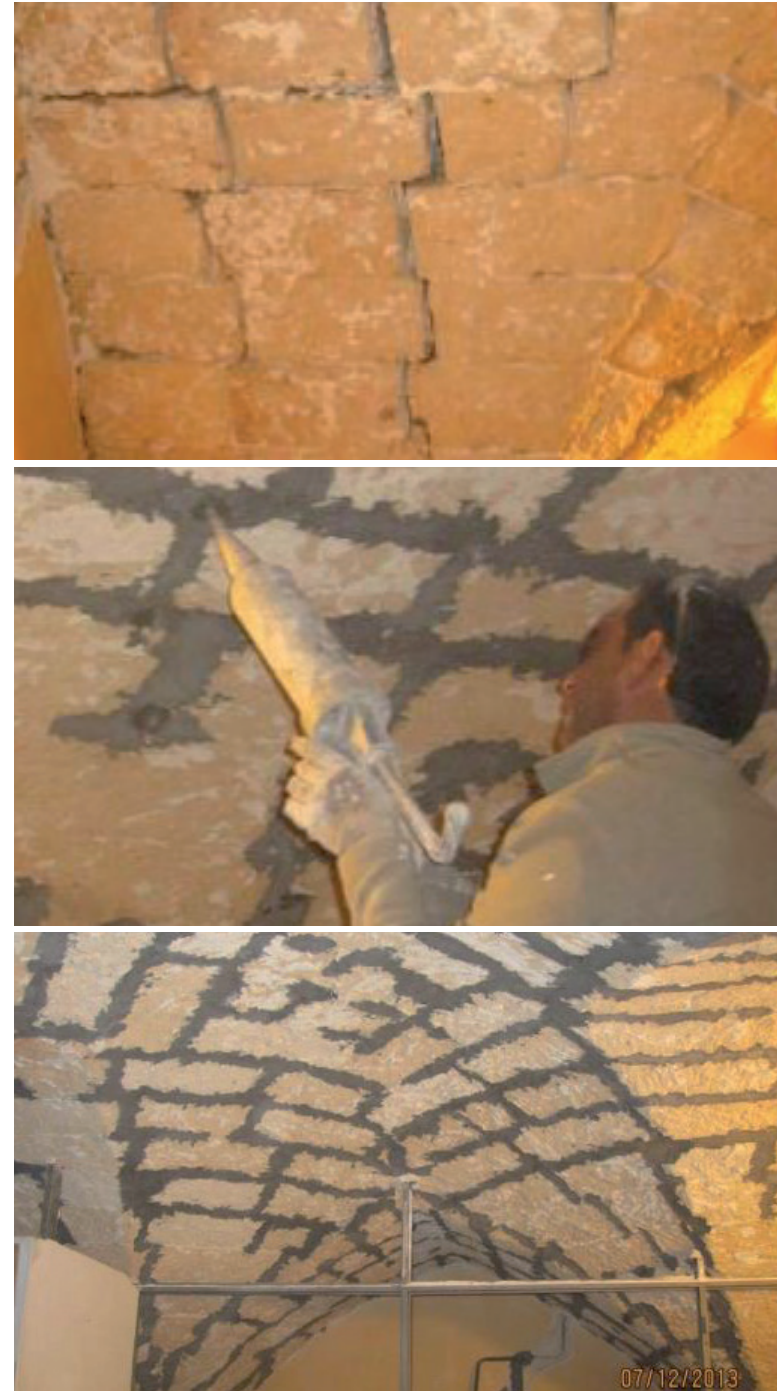

Figure 17. Injection of mortar at the vault intrados. a) before strengthening $b$ ) strengthening $c$ ) after strengthening. 


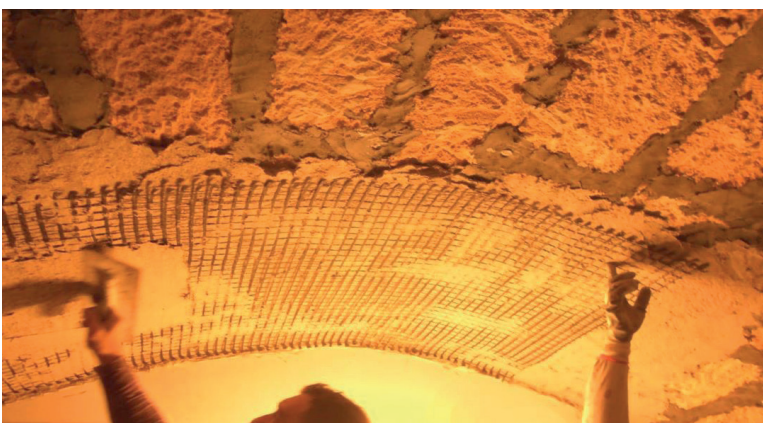

Figure 18. Installation of FRCM glass fiber system.

After the safety of the vault was guaranteed the strengthening protocol of the masonry walls was applied. In order to reduce the effects of the thrusts of the vaults on the masonry walls that can also be prone to shear under seismic forces, it was decided to apply pre-loaded steel tendons, which should be anchored to the masonry walls by means of reacting steel plates. This was possible since the length of the tendons was not so high to create construction problems or excessive costs for the installation. In order to achieve a seismic retrofitting of the building, respect to possible local mechanism that may involve the external walls under seismic forces it was decided to confine the entire building by means of pre-tensioned CFRP wires that were placed at two different height levels, corresponding to the lines of the thrusts of the vaults on both floors. The strengthening scheme is illustrated in figure 19 for the first floor, in which the lines in blue and red color indicate the steel tendons, while the external green line represents the continuous CFRP wires that were positioned on both floors.

figure 20 illustrates the strengthening phases, which are the same as followed for the case study 1 of the present paper. figure 21 illustrates how the design pre-tensioning load was controlled by measuring the elongation of the wire through the advancement of the screwed terminal region outside the steel anchorage.

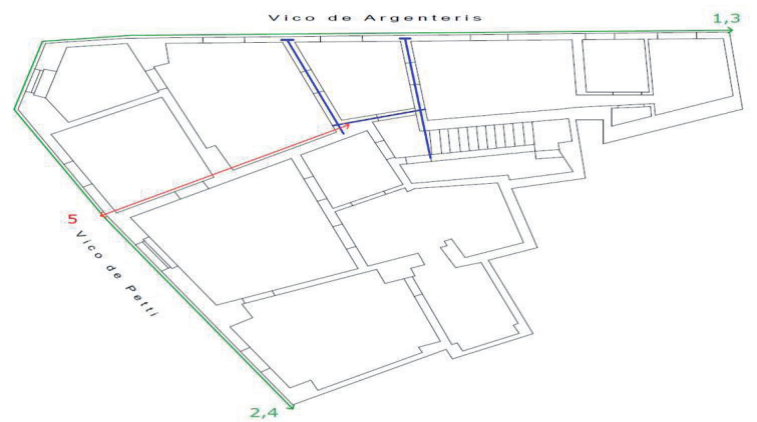

Figure 19. Positions of the pre-tensioned steel and CFRP tendons.
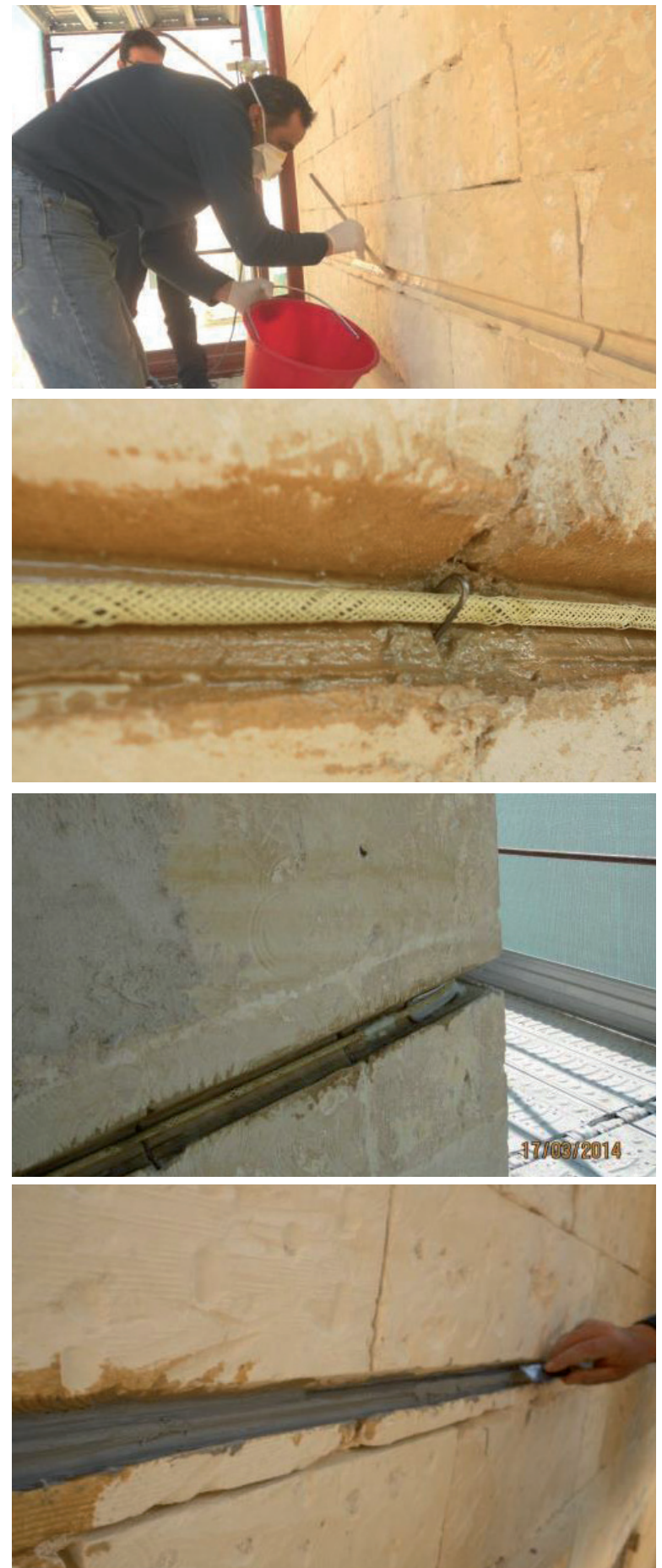

Figure 20. Application of the CFRP pre-tensioned wires.

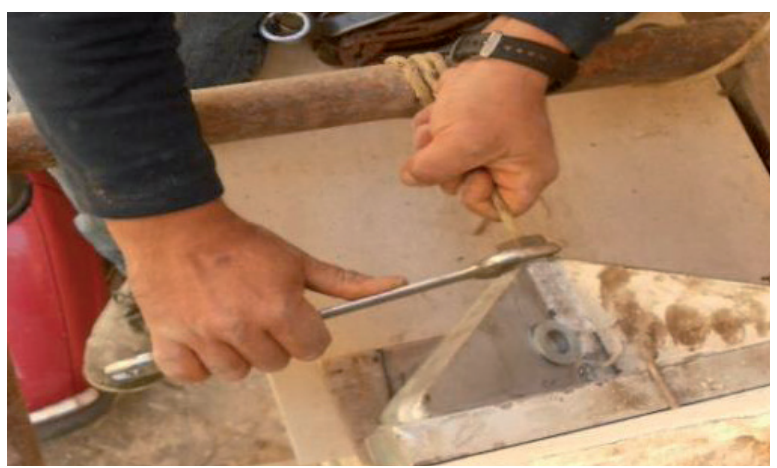




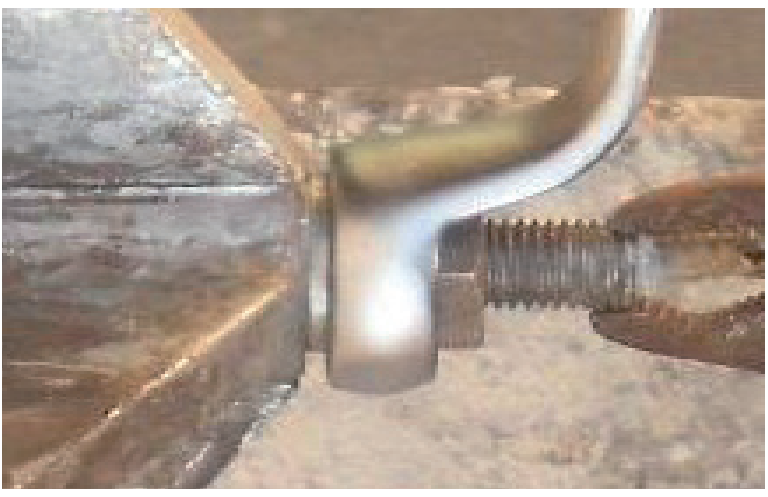

Figure 21. Controlled pre-tensioning and anchorage of the CFRP wires.

CONCLUSIONS

Two case of seismic upgrade were presented and discussed in the paper with reference to masonry construction. A large building used as public theatre and a civil building with two floors were studied from a theoretical and experimental point of view. It was seen that for masonry buildings, which were not designed according to a specific technical code the processes of the structural knowledge and monitoring are fundamental in order to achieve the necessary data for analysis.

Clobal analysis, usually performed by creating a finite element model should be accompanied by a kinematic analysis in order to catch properly the real seismic vulnerability of the building. Linear and non linear approach can be used, by knowing that the first one is easy and conservative, the second one is accurate but more complex.

When slender walls are present or the walls are already subjected to horizontal forces arising from the vaults thrusts, a possible limit state, under seismic forces, can be represented by the rotation of the walls. Therefore a device that can be able to inhibit this kind of kinematic evolution of the structure is necessary. For this purpose it was seen and demonstrated that innovative composite materials in forms of pretensioned carbon fiber wires represent a valid and cheap solution.

\section{REFERENCES}

1. Italian Ministry of Infrastructure and Transportation (2009) Circolare 2 febbraio 2009, n. 617 - Istruzioni per l'applicazione delle "Nuove norme tecniche per le costruzioni» di cui al decreto ministeriale 14 gennaio 2008 (in Italian).

2. ISCARSAH - International Scientific Committee for Analysis and Restoration of Structures of $\mathrm{Ar}^{-}$ chitectural Heritage - "Recommendations for the analysis, conservation and structural restoration of architectural heritage", Barcelona, 5 June 2005, $39 \mathrm{pp}$. 